\title{
Induction of cell-specific apoptosis and protection from Dalton's lymphoma challenge in mice by an active fraction from Emilia sonchifolia
}

\author{
B. S. Shylesh, ${ }^{*}$ S. Ajikumaran Nair, A. Subramoniam
}

Palode,
Tropical Botanic Garden
and Research Institute,
Paruvananthapuram, India
*Present address:
Thiruther
Department of Pathology,
Louisiana State University
and Health Science Center,
New Orleans, LA-70112,
USA
Received: 21.2.2005
Revised: 7.5.2005
Accepted: 15.5.2005
Correspondence to:
A. Subramoniam
E-mail:
asubramoniam@yahoo.com

\begin{abstract}
Objective: To isolate an active anticancer fraction from Emilia sonchifolia and to determine the mechanism of its anticancer activity.

Materials and methods: The anticancer principle was separated using thin layer chromatography (TLC) from the most active n-hexane extract and chemically analysed. The anticancer efficacy of n-hexane extract was determined in mice using Dalton's lymphoma ascitic (DLA) cells. Cytotoxicity of the extracts and isolates to macrophages, thymocytes and DLA cells was measured using Trypan blue exclusion method, MTT (3-[4,5-Dimethylthiazol2-yl]-2,5-diphenyl tetrazolium bromide) assay, DNA ladder assay and DNA synthesis in culture. Short-term toxicity evaluation of the active fraction was also carried out in mice. Results: The hexane extract was found to be most active and it showed in vitro cytotoxicity to DLA and thymocytes, but not to macrophages. In a concentration and time-dependent manner, it induced membrane blebbing, nuclear condensation, DNA ladder formation, and formation of apoptotic bodies which are characteristic to apoptotic cell death. The n-hexane fraction protected $50 \%$ of mice challenged intraperitoneally with $10^{6}$ DLA cells. This fraction did not exhibit conspicuous adverse toxic symptoms in mice. An active terpene fraction was separated from the n-hexane extract by TLC. This isolate induced apoptotic cell death in DLA cells at $0.8 \mu \mathrm{g}$ per $\mathrm{mL}$ level.

Conclusion: An anticancer terpene fraction was isolated by TLC from Emilia sonchifolia that induced cell-specific apoptosis and appears to be a promising anticancer agent.
\end{abstract}

KEY WORDS: Anticancer herbal extract, terpene, apoptosis, thymocytes, macrophages.

\section{Introduction}

Emilia sonchifolia (L.) DC. ex Wt. (Compositae), is an herbaceous plant found in India and in other Asian countries. ${ }^{[1]}$ The plant is used in folklore medicine for the treatment of tumor, inflammation, cough, rheumatism, cuts, and wounds. In China, the leaves of this plant are used against fever and dysentery. ${ }^{21}$ The water extract of this plant showed antimicrobial activity. ${ }^{[3]}$ The aerial part of the plant has been reported to contain alkaloids, ${ }^{[4]}$ flavonoids, and terpenes. ${ }^{[3]}$ Earlier, based on the limited studies, it has been reported that the alcohol extract of this plant (aerial part) has cytotoxicity, as well as anti Ehrlich ascitic carcinoma (EAC) and anti Dalton's lymphoma ascites (DLA) activities in mice..$^{[5]}$ In the present study, the earlier findings were extended, an active n-hexane fraction (extract) was isolated and the induction of cell-specific apoptosis by the active fraction was discovered. The active principle was separated by TLC and identified as terpene. A preliminary short-term toxicity evaluation of the active fraction was also carried out in mice.

\section{Materials and methods}

\section{Plant material}

Emilia sonchifolia, collected locally from Thiruvananthapuram District, Kerala, was used for the studies. It was identified and compared with the herbarium specimen preserved at the Tropical Botanic Garden and Research Institute (TBGRI) by taxonomists of TBGRI.

\section{Preparation of extracts}

The collected plants were washed thoroughly in tap water, dried in shade, and powdered. The powder was extracted sequentially at room temperature with different solvents: nhexane, ethyl acetate, ethyl alcohol, butanol and water essentially as described elsewhere. ${ }^{[6]}$ At each step, the extraction was done 3 times with fresh solvent to ensure complete extraction. The extracts were dried in a rotary 
evaporator at $40^{\circ} \mathrm{C}$ except for water extract that was freeze dried.

\section{Animals}

Inbred Swiss albino mice (6-7 week old), reared in the TBGRI animal house, were used. Animals were caged in uniform hygienic conditions and fed with standard pellet diet (Lipton, India Laboratories, Banglore) and water ad libitum. Clearance was obtained from the Institute Animal Ethics Committee to conduct these experiments.

\section{Chemicals}

RPMI-1640 medium, phosphate buffered saline (PBS), streptomycin, and penicillin were purchased from High Media, India Limited. RNA-ase A, proteinase K, 3-[4, 5-dimetylthiazol2yl]-2, 5-diphenyl tetrazolium bromide (MTT), agarose, ethidium bromide, vincristine, and curcumin were purchased from Sigma Aldrich, St. Louis, USA. Methyl- ${ }^{3} \mathrm{H}-$ thymidine was purchased from the Board of Radiation and Isotope Technology (BRIT), Mumbai, India.

Cell lines

Dalton's lymphoma ascitic (DLA) cells, originally obtained from Amala Cancer Research Centre, Thrissur, India, were propagated as transplantable tumors in the peritoneal cavity of mice.

\section{Thymocyte preparation}

The thymus glands were removed from the mice carefully and trimmed off from the adjoining lymph nodes. Single-cell suspensions were prepared in cold RPMI -1640 medium and viability assessed by Trypan blue exclusion method. ${ }^{[7]}$

\section{Collection of macrophages}

Peritoneal exudates cells (PEC) were collected by injecting $5 \mathrm{ml}$ chilled RPMI-1640 medium in peritoneal cavity of mice. The glass adherent cell population (macrophages) was separated by adhering PEC over glass petri-dish at $37{ }^{\circ} \mathrm{C}$ for 2 hours in a $\mathrm{CO}_{2}$ incubator having $5 \% \mathrm{CO}_{2}$ in air. The viable cell count was done using Trypan blue in a Neubauer counting chamber.

\section{In vitro cytotoxicity assay}

Short-term cytotoxicity of extracts was assessed by incubating $1 \times 10^{6}$ DLA cells, thymocytes or macrophages in $1 \mathrm{ml}$ PBS containing different concentrations of extract. The cell viability was assessed by the Trypan blue exclusion method. ${ }^{[7]}$ Long-term cytotoxicity of extracts/fractions to DLA cells was determined by seeding $1 \times 10^{6}$ cells in 24 -well-plate containing $1 \mathrm{ml}$ RPMI-1640 medium supplemented with 10\% FBS (fetal bovine serum), streptomycin $(100 \mu \mathrm{g} / \mathrm{ml})$ and penicillin (100 units $/ \mathrm{ml})$. The cells were grown at $37^{\circ} \mathrm{C}$ in a humidified atmosphere in 4\% $\mathrm{CO}_{2}$ and $96 \%$ air. The cell viability was determined by the Trypan blue exclusion method. ${ }^{[7]}$ The toxicity was also determined by MTT assay. It was performed essentially as described earlier. ${ }^{[8]}$ Briefly $1 \times 10^{6}$ cells in one ml were seeded in 24-well-plate and the cells were exposed to different concentrations of n-hexane extract. After incubation, MTT solution $(1.2 \mathrm{mg} / \mathrm{ml})$ was added to each well and cells were incubated for an additional $4 \mathrm{~h}$. The MTT formazan product was dissolved in DMSO and the color was estimated using Elisa plate reader at $570 \mathrm{~nm}$ absorbance.

${ }^{3}$ H-thymidine incorporation assay

DLA cells were cultured in RPMI-1640 containing $1 \mu \mathrm{Ci} / \mathrm{ml}$ ${ }^{3} \mathrm{H}$-thymidine. The cells were exposed with different concentrations of $\mathrm{n}$-hexane fraction at $37^{\circ} \mathrm{C}$ for $5 \mathrm{~h}$. The radioactivity was measured, as described elsewhere, by liquid scintillation counter. ${ }^{[9]}$

\section{Apoptosis}

Because membrane blebbing was observed during cytotoxicity assay, a detailed study was carried out to determine whether or not the hexane extract induces apoptotic cell death. Morphological observation and DNA-ladder formation assay were carried out. Morphological evidence was determined by using acridine orange and ethidium bromide ( $\mathrm{AO} / \mathrm{EtBr})$ staining. ${ }^{[10]}$ Cells $\left(1 \times 1^{6}\right)$ were seeded in 24 -well-plate along with various concentrations of n-hexane extract and curcumin (a positive control) at $37^{\circ} \mathrm{C}$ for 4 hours. The cells were washed with PBS and treated with AO/EtBr $(100 \mu \mathrm{g} / \mathrm{ml}$ PBS of each dye). The cells were observed under fluorescent microscopy using a blue filter, and photographed (ASA-400 Kodak); nonviable cells were observed in red-orange color. (The damaged membrane allows EtBr to enter and will appear as red-orange color).

\section{DNA ladder assay}

DLA cells $\left(1 \times 10^{6}\right)$ were seeded in 24-well-plate containing RPMI medium, along with various concentrations of n-hexane fraction and curcumin and incubated for $24 \mathrm{~h}$ in $4 \% \mathrm{CO}_{2}$ and $96 \%$ air. After incubation, cells were harvested and washed with PBS and pelleted by centrifugation (300 rpm). To the cell pellet, $100 \mu \mathrm{L}$ lyses buffer (50 mM Tris - HCl pH 8., $20 \mathrm{mM}$ EDTA, $10 \mathrm{mM} \mathrm{NaCl}, 1 \%$ SDS) was added for $1 \mathrm{~min}$ and centrifuged at $2000 \mathrm{rpm}$ for $5 \mathrm{~min}$. The supernatant was collected and incubated with RNase A ( $5 \mu \mathrm{g} / \mathrm{ml})$ for 1 hour followed by digestion of proteins with proteinase $\mathrm{K}(100 \mu \mathrm{g} /$ $\mathrm{ml})$ for 5 hours. Aliquots of lysate $(20 \mu \mathrm{L})$ were loaded to $1.5 \%$ agarose prepared in TBE buffer [Tris-Borate $45 \mathrm{mM}, 1 \mathrm{mM}$ EDTA, pH 8] containing $3 \mu \mathrm{g} / \mathrm{ml}$ EtBr, and DNA was separated by electrophoresis. The separated DNA fragments in the gel were visualized by the gel-documentation system.

Antitumor activity of $n$-hexane extract in mice

Antitumor activity of n-hexane extract was determined, as described previously. ${ }^{[5,11]}$ Briefly, 48 Swiss albino mice (20-25 g) were challenged with DLA cells $\left(1 \times 10^{6}\right.$ cells, i.p $)$ and divided into 6 groups of 8 each. Group I: Served as control, received $1 \%$ gum acacia orally. The groups, II, III and IV received the n-hexane extract/fraction of $E$. Sonchifolia 50, 100, and $250 \mathrm{mg} / \mathrm{kg}$, b.w., respectively; the groups $\mathrm{V}$ and VI received 0.5 and $1 \mathrm{mg} / \mathrm{kg}$, b.w., vincristine, respectively, orally for 15 days. (Vincristine was used as a standard anticancer agent for comparison).

\section{Chemical analysis of n-hexane extract}

The n-hexane extract was subjected to chemical analysis to determine the classes of compounds present in it. ${ }^{[2]}$ The extract was tested for the presence of alkaloid (Dragendorff reagent and Mayer's reagent), coumarin (Borntagrs reaction), flavonoid (Shinoda test), steroid (Liberman Burchard test), steroid, and terpene (vanillin- sulphuric acid reagent). The nhexane fraction was subjected to silica gel thin layer chromatography (TLC) using n-hexane:chloroform:methanol (5:4.5:0.5) as a solvent system. The chromatograms were sprayed with Libermann-Burchard reagent or vanillinsulphuric acid reagent and heated at $100{ }^{\circ} \mathrm{C}$ and inspected. ${ }^{[12]}$ The chromatogram showed several terpenoid and steroid 
spots. Each spot in preparative TLC was identified (with the help of a reagent sprayed plate run simultaneously) on the basis of relative mobility and scrapped off and eluted with nhexane and tested for apoptotic cell death induction in DLA cells.

\section{Preliminary toxicity evaluation}

To determine the preliminary toxicity, 3 groups of animals $(\mathrm{n}=6)$ were administered orally, 0 (control), 250 and 500 $\mathrm{mg} / \mathrm{kg}$ of the $\mathrm{n}$-hexane extract, respectively, for 30 days. The control group received $1 \%$ gum acacia in an identical manner. Body weight, food and water intake, and general behavior were observed. After 30 days the animals were sacrificed and blood was collected; organs (thymus, spleen, liver, and kidney) were removed and weighed. Hematological parameters were determined, as described elsewhere. ${ }^{[13]}$ Serum glutamate pyruvate transaminase (SGPT) and serum glutamate oxalate transaminase (SGOT) were estimated by the method of Reitman and Frankel; ${ }^{[14]}$ serum alkaline phosphatase (AP) was estimated by the Kind and King's method ${ }^{[15]}$ using commercial kit; urea was estimated colorimetrically using commercial kit (Span diagnostics, India); cholesterol was estimated, as described elsewhere; ${ }^{[16]}$ glucose was estimated enzymatically by GOD/ POD method.

\section{Results}

\section{Cytotoxicity}

Cells (DLA, thymocytes and macrophages) were treated with different extracts/fractions of $E$. sonchifolia, that is, nhexane, ethyl acetate, butanol and water and viability was measured by the Trypan blue exclusion method. [Table 1] The n-hexane fraction was the most potent in inducing cytotoxicity. The $\mathrm{IC}_{50}$ values of n-hexane fraction were $32 \mu \mathrm{g} / \mathrm{ml}$ for DLA cells and $30 \mu \mathrm{g} / \mathrm{ml}$ for thymocytes. Interestingly the fraction was non-toxic to mouse peritoneal macrophages. [Table 2] Ethyl acetate and alcohol fractions showed moderate toxicity, whereas butanol and water fractions were inactive. The $\mathrm{IC}_{50}$ values of curcumin (reference drug) were found to be 22, 24 and $32 \mu \mathrm{g} / \mathrm{ml}$ for DLA, thymocytes and macrophages, respectively. The yield of the active n-hexane fraction was unusually high in this plant. It was approximately $26 \%$ of the whole plant powder. The active terpene isolate from the nhexane fraction showed $100 \%$ cytotoxicity to DLA cells at a low concentration of about $0.8 \mu \mathrm{g} / \mathrm{ml}$.

MTT assay also showed the cytotoxicity of n-hexane fraction of $E$. sonchifolia. The fraction showed a concentrationdependent cytotoxicity to cultured DLA cells that was almost comparable to curcumin. [Figure 1]

\section{Thymidine incorporation}

DNA synthesis was measured by assaying tritiated thymidine incorporation into DNA. As shown in Figure 2, the n-hexane fraction inhibited DNA synthesis in both DLA and thymocytes in a concentration-dependent manner.

\section{Mechanism of cytotoxic action}

To investigate the type of cell death by n-hexane fraction, cells were stained with $\mathrm{AO} / \mathrm{EtBr}$, which allows the identification of viable, apoptotic, and dead cells on the basis of color and appearance. The cells treated with $50 \mu \mathrm{g} / \mathrm{ml}$ of the n-hexane fraction showed membrane blebbing, nuclear condensation, and DNA ladder formation.[Figure 3] Almost similar
Table 1

Cytotoxicity of different extracts of $E$. sonchifolia on DLA cells incubated at $37^{\circ} \mathrm{C}$ in phosphate buffered saline

\begin{tabular}{lcc}
\hline Test material & Quantity of extract $(\boldsymbol{\mu g} / \mathbf{m l})$ & \% cell death \\
\hline 0.1\% DMSO (Control) & 0 & 0 \\
Hexane extract & 10 & $23 \pm 2.5$ \\
& 25 & $45 \pm 5.3$ \\
& 50 & 100 \\
Ethyl acetate extract & 100 & 100 \\
& 10 & 0 \\
& 25 & $5 \pm 1$ \\
Alcohol extract & 50 & $15 \pm 3.7$ \\
& 100 & $20 \pm 5.5$ \\
& 10 & 0 \\
Butanol extract & 25 & 0 \\
& 50 & $7 \pm 1.6$ \\
& 100 & $12 \pm 3.5$ \\
& 10 & 0 \\
Water extract & 25 & 0 \\
& 50 & 0 \\
& 100 & 0 \\
& 10 & 0 \\
& 25 & 0 \\
& 50 & 0 \\
\hline
\end{tabular}

Values are mean \pm SD of 3 separate determinations

\section{Table 2}

In vitro cytotoxicity of $\mathbf{n}$-hexane extract to different cells incubated for $3 \mathrm{~h}$ in phosphate buffered saline

\begin{tabular}{|c|c|c|c|}
\hline \multirow[t]{2}{*}{ Test material $(\mu \mathrm{g} / \mathrm{ml})$} & \multicolumn{3}{|c|}{$\%$ cell death } \\
\hline & $D L A$ & Thymocytes & Macrophages \\
\hline $\begin{array}{l}0.1 \% \text { DMSO } \\
\text { (n-hexane extract) }\end{array}$ & 0 & 0 & 0 \\
\hline 10 & $23 \pm 4$ & $15 \pm 4.3$ & 0 \\
\hline 20 & $44 \pm 3.5$ & $30 \pm 50$ & 0 \\
\hline 30 & $52 \pm 5$ & $50 \pm 4.3$ & 0 \\
\hline 40 & $75 \pm 6.5$ & 100 & 0 \\
\hline 50 & 100 & 100 & 0 \\
\hline \multicolumn{4}{|l|}{ Curcumin } \\
\hline 10 & $10 \pm 4.2$ & $15 \pm 3$ & $24 \pm 5.5$ \\
\hline 20 & $30 \pm 5.0$ & $25 \pm 6$ & $35 \pm 6.7$ \\
\hline 30 & $45 \pm 7.0$ & $45 \pm 4.6$ & $46 \pm 2$ \\
\hline 40 & 100 & 100 & 100 \\
\hline 50 & 100 & 100 & 100 \\
\hline
\end{tabular}

$\mathrm{DLA}=$ Dalton's lymphoma ascitic cells; Values are mean $\pm S D$ of 3 separate determinations

observations were observed in cells treated with curcumin also [Figure 3].

\section{Antitumor activity of $n$-hexane fraction}

The n-hexane fraction of $E$. sonchifolia exhibited remarkable antiDLA activity in mice. Administration of the n-hexane fraction ( $250 \mathrm{mg} / \mathrm{kg}$; dose based on the previous preliminary study) orally for 15 days, resulted in complete protection of 4 
Figure 1. Cytotoxicity of $E$. sonchifolia (n-hexane fraction) determined by MTT assay 1 - Control (0.1\% DMSO); 2, 3 and 4 are 2.5, 5 and 10 $\mu \mathrm{g} / \mathrm{ml} \mathrm{n}$-hexane fraction in $0.1 \%$ DMSO respectively; 5,6 and 7 are $2.5,5$ and $10 \mu \mathrm{g} / \mathrm{ml}$ curcumin in $0.1 \%$ DMSO respectively

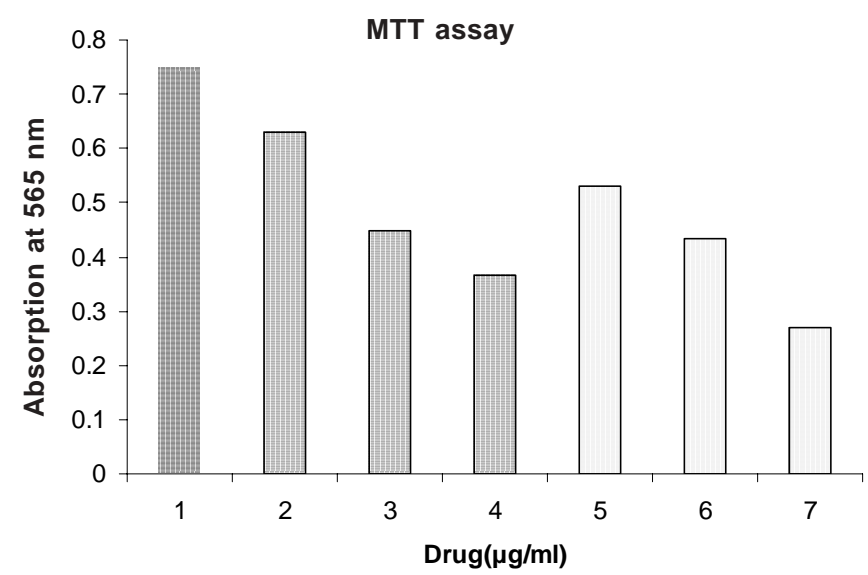

Figure 3. Induction of apoptosis in Dalton's Lymphoma Ascites (DLA) cells by Emila sonchifolia (hexane fraction)
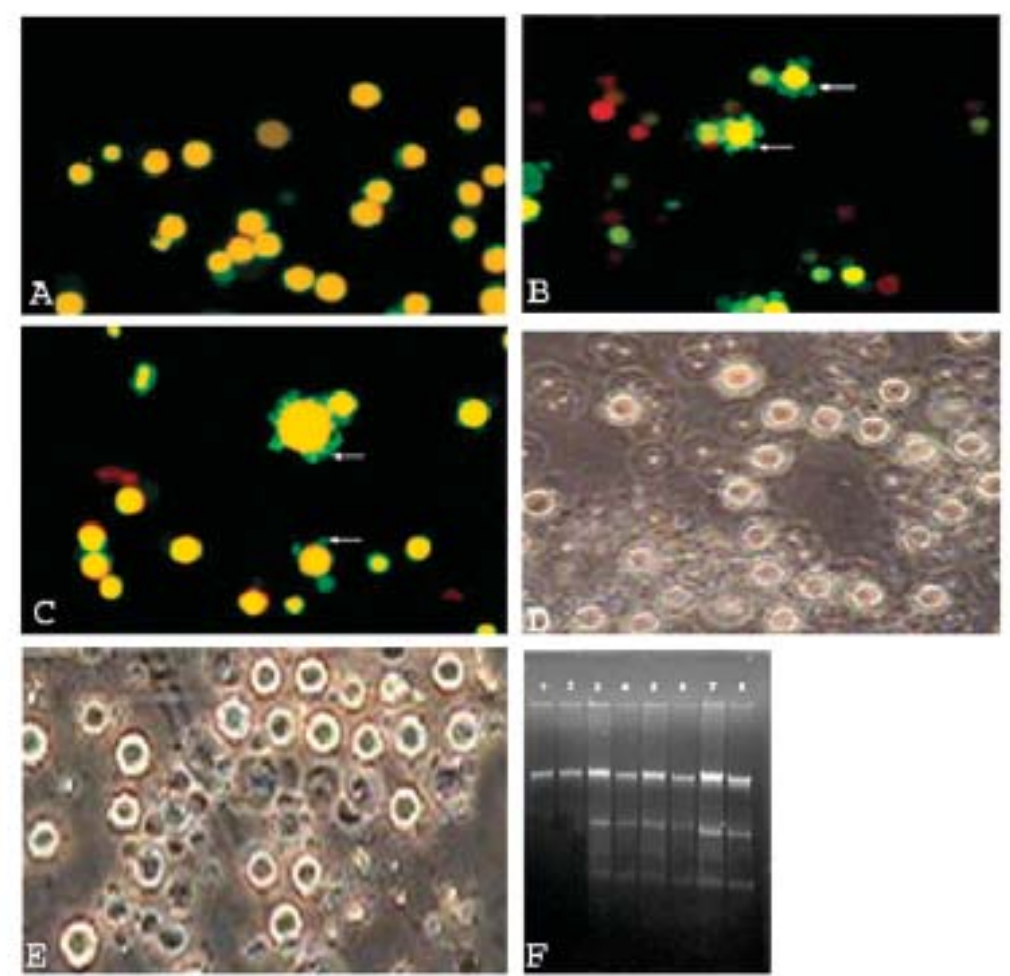

A - Control (stained with acridine orange and ethidium bromide); $\mathrm{B}$ - hexane fraction $(50 \mu \mathrm{g} / \mathrm{ml})$ treated cells showing membrane blebbing; C - curcumin $(25 \mu \mathrm{g} / \mathrm{ml}) ; \mathrm{D}$ - normal DLA cells [phase contrast]; $\mathrm{E}$ - hexane fraction treated $(50 \mu \mathrm{g} / \mathrm{ml})$ cells showing nuclear condensation. F - Electrophoretic separation of normal (control) and fragmented (treated) DNA, Lanes 1 and 2: DNA from $1 \times 10^{6}$ control cells; 3 to 6 : Hexane fraction treated $(3: 25 \mu \mathrm{g} /$ $\mathrm{ml}, 1 \times 10^{6}$ cells; $4: 25 \mu \mathrm{g} / \mathrm{ml}, 0.5 \times 10^{6}$ cells; $5: 50 \mu \mathrm{g} / \mathrm{ml}, 1 \times 10^{6} ; 6: 50 \mu \mathrm{g} /$ $\left.\mathrm{ml}, 0.5 \times 10^{6}\right) ; 7$ and 8: curcumin $(25 \mu \mathrm{g} / \mathrm{ml})$ treated $\left(7: 1 \times 10^{6}\right.$ cells; $8: 0.5$ $\mathrm{x} 10^{6}$ cells) [Details given in materials and methods]
Figure 2. Inhibition of ${ }^{3} \mathrm{H}$-thymidine incorporation in DLA cells by $\mathrm{n}$ hexane fraction of $E$. sonchifolia

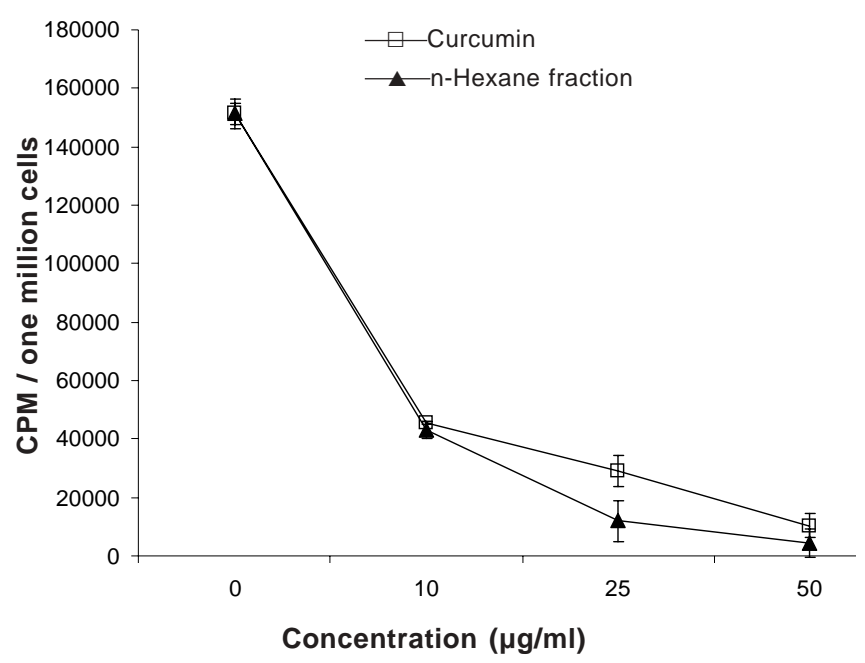

Figure 4. Thin layer chromatographic separation of $n-$ hexane fraction from Emilia sonchifolia. The arrow indicates the triterpene, active principle.

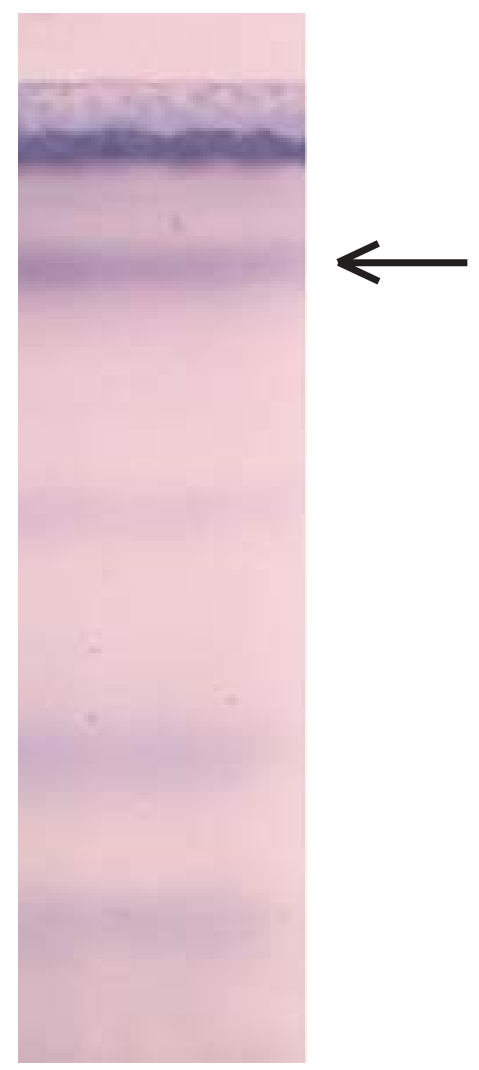


Table 3

Antitumor activity of $n$-hexane extract of $E$. sonchifolia in mice challenged with Dalton's lymphoma ascitic cells

\begin{tabular}{ccccccc}
\hline \begin{tabular}{l} 
Days (after $\begin{array}{l}\text { tumor } \\
\text { challenge)* }\end{array}$ \\
\cline { 2 - 7 }
\end{tabular} & Control & $\begin{array}{c}\text { Number of surviving animals } \\
\text { (mg/kg, } \boldsymbol{~ b . w . ) ~}\end{array}$ & $\begin{array}{c}\text { Vincristine } \\
(\mathbf{m g} / \mathbf{k g}, \boldsymbol{b} . \boldsymbol{w} .)\end{array}$ \\
\hline & & 50 & 100 & 250 & 0.5 & 1 \\
\hline 1 & 8 & 8 & 8 & 8 & 8 & 8 \\
10 & 8 & 8 & 8 & 8 & 8 & 8 \\
15 & 8 & 8 & 8 & 8 & 8 & 8 \\
20 & 0 & 4 & 8 & 8 & 8 & 8 \\
25 & 0 & 0 & 2 & 8 & 6 & 8 \\
40 & 0 & 0 & 0 & 4 & 0 & 4
\end{tabular}

*Mice were challenged with $1 \times 10^{6}$ cells (i.p.). The herbal drug was administered daily from the day of tumour challenge, for 15 days (the time period required for the death of all the animals in the control group was 17).

out of 8 DLA- challenged mice. Further, it prolonged the life span of treated mice which died, compared to untreated controls. Lower doses (50 and $100 \mathrm{mg} / \mathrm{kg}$ ) of the fraction were found to be not very effective. [Table 3] The results were comparable with those of standard anticancer agent vincristine.

Chemical analysis

Chemical analysis of the n-hexane fraction showed the presence of steroids and terpenes and absence of alkaloid and flavonoid. [Figure 4] When the steroids and terpenes were separated by thin layer chromatography and each band (fraction) was tested for cytotoxicity, one terpene band showed activity and the other bands were inactive. The active band was identified as terpene. This was a fast-moving terpene band in n-hexane: chloroform: methanol (5: 4.5: 0.5) solvent system. [Figure 4] (The concentration required for this isolate for $100 \%$ cytotoxicity to DLA cells was approximately $0.8 \mu \mathrm{g} / \mathrm{ml}$ ).

Toxicity evaluation in mice

The results of general short-term (30 days) toxicity study in mice are given in Table 4 . The extract administered at the therapeutic dose $(250 \mathrm{mg} / \mathrm{kg})$ and a dose double than that $(500 \mathrm{mg} / \mathrm{kg}$ ) did not substantially influence the body weight, weight of organs (liver, kidney, thymus and spleen) and food and water intake (data not shown). The treatment also did not alter most of the serum biochemical parameters (SGPT, SGOT, urea, glucose). However, it marginally decreased serum cholesterol levels, which was significant at $500 \mathrm{mg} / \mathrm{kg}$ dose level. AP increased marginally. However, its levels in the treated animals were within the normal range. Hemoglobin level and peritoneal macrophage number were also not significantly altered. Although the number of peritoneal macrophages showed an increasing trend, it fell short of statistical significance. However, the number of total white blood cells (WBC) decreased significantly. [Table 4]

\section{Discussion}

In the present study, it has been shown clearly that the nhexane fraction from $E$. sonchifolia, as well as the terpene isolated from the extract, induced cell-specific apoptosis. Although there are a lot of herbal extracts or isolated compounds with varying levels of anticancer activity, they are rarely cell specific. ${ }^{[17]}$ Similarly curcumin, a common antioxidant and antiinflammatory agent, also showed comparable cytotoxicity and it was not cell specific. The cytotoxicity of nhexane extract and terpene isolate from $E$. sonchifolia were found to be cell specific. The extract was not toxic to macrophages, whereas it was toxic to thymocytes and cancer cells tested in the present study. Earlier preliminary studies have shown that the extract of $E$. sonchifolia was toxic to Ehrlich ascitic carcinoma (EAC) cells and transformed mouse lung fibroblasts, and not toxic to normal human peripheral lymphocytes. ${ }^{[5]}$ Therefore, it is likely that it could be active against specific types of cancer cells sparing almost all normal cells except sensitive cells like thymocytes. Further, it is of interest to note that a dose much higher than the therapeutic dose did not show severe adverse toxic manifestations in mice. However, the significant reduction in total WBC needs further evaluation. The sensitivity of thymocytes (probably immature T-cells) to the herbal drug may account, at least, partly to this observed reduction in WBC. This may affect the normal function of immune system. The moderate increase in alkaline phosphatase (AP) observed in the toxicity study may suggest minor damage to some cells in one or more organs such as bone and intestine which are rich sources of AP. Because serum transaminase levels were not changed, liver damage and entry of liver AP into the circulation is highly unlikely.

\section{Table 4}

Effect of $n$-hexane extract of $E$. sonchifolia on serum biochemical and hematological parameters

\begin{tabular}{|c|c|c|c|c|c|c|c|c|c|}
\hline \multirow[t]{2}{*}{ Groups } & \multicolumn{6}{|c|}{ Biochemical parameters } & \multicolumn{3}{|c|}{ Hematological parameters } \\
\hline & $\begin{array}{l}\text { SGPT } \\
(I U / L)\end{array}$ & $\begin{array}{l}\text { SGOT } \\
(I U / L)\end{array}$ & $\begin{array}{l}A P \\
(K A)\end{array}$ & $\begin{array}{c}\text { Urea } \\
(m g / d L)\end{array}$ & $\begin{array}{c}\text { Cholesterol } \\
\text { (mg/dL) }\end{array}$ & $\begin{array}{l}\text { Glucose } \\
\text { (mg/dL) }\end{array}$ & $\begin{array}{c}H b \\
(g \%)\end{array}$ & $\begin{array}{c}\text { WBC } \\
\left(10^{6} / \mathrm{ml}\right)\end{array}$ & $\begin{array}{r}\text { Macrophages/ } \\
\text { mouse }\left(10^{6}\right)\end{array}$ \\
\hline 250 & $40.0 \pm 2.3$ & $64.0 \pm 4.1$ & $14.9 \pm 1.7^{*}$ & $40.8 \pm 2.20$ & $109.3 \pm 3.9^{*}$ & $98.7 \pm 2.9$ & $13.6 \pm 0.6$ & $3.73 \pm 1.28^{* *}$ & * $\quad 6.19 \pm 0.69$ \\
\hline 500 & $38.4 \pm 2.8$ & $67.2 \pm 4.1$ & $15.7 \pm 0.9^{*}$ & $50.50 \pm 4.95$ & $93.8 \pm 8.6^{* *}$ & $102.0 \pm 9.5$ & $13.1 \pm 0.14$ & $5.50 \pm 0.42^{* *}$ & * $\quad 7.14 \pm 0.81$ \\
\hline ANOVA & $\mathrm{P} \quad \mathrm{ns}$ & $\mathrm{ns}$ & $<0.001$ & ns & $<0.001$ & ns & ns & $<0.001$ & ns \\
\hline
\end{tabular}

The drug was given daily for 30 days. 6 animals were used in each group. Values are mean $\pm S D ; d f=2,15 ;{ }^{*} P<0.01$, ${ }^{* *} P<0.001$ (One-way $A N O V A$ followed by Dunnett's test); SGPT- Serum glutamate pyruvate transaminase; SGOT- Serum glutamate oxalate transaminase; AP- Alkaline phosphatase. ns - not significant. 
Further, normal morphology and weight of the liver were not affected by the treatment.

The mild decrease in serum cholesterol level may be considered as a beneficial side effect.

The n-hexane fraction and/or the active terpene are attractive materials for drug development. However, a detailed study is required about the sensitivity of different normal cells to the herbal drug under in vivo conditions. It is of interest to note, the in vivo efficacy of the hexane fraction $(250 \mathrm{mg} / \mathrm{kg}$ ) against Dalton's Lymphoma was equal to vincristine (1 mg/ $\mathrm{kg}$ ). The dose of vincristine used was the maximum-tolerable dose, whereas in the case of the hexane fraction, a higher dose is possible without conspicuous major toxic manifestations. However, there is an urgent need to test the efficacy of this drug in various cancer models. Such studies in this laboratory in various animal cancer models are underway.

It is known that antioxidants can inhibit proliferation of at least certain types of cancers. ${ }^{[18,19]}$ Agents that show antiinflammatory activity by inhibiting cyclo-oxygenase can also retard cell proliferation. ${ }^{[19]}$ Previous studies have shown that the extract of $E$. sonchifolia has both antiinflammatory and antioxidant properties. ${ }^{[20]}$ It remains to be studied whether or not the antiinflammatory and antioxidant activities are exerted by the apoptosis inducing terpene identified in the present study. It is likely that the antitumour terpene could have more than one molecular target in exhibiting its anticancer action. At any rate, the present study establishes the likely anticancer potential of $E$. sonchifolia.

Studies in progress in this laboratory include structural identification of the terpene active principle, as well as the mechanism of action studies which include the molecular event that triggers the chain of events leading to apoptotic cell death.

$E$. sonchifolia is an annual herb which grows as a weed. This can be easily cultivated, and the plant material can be made available in sufficient quantities as and when needed for drug development. However, the cultivation conditions that yield maximum bio-active material have to be studied.

\section{Acknowledgments}

One of the authors, (Dr. B.S. Shylesh) gratefully acknowledges, CSIR, Govt. of India, for having provided a Research Associate position to carry out this study. The authors express their sincere thanks to Mr. G. Santhoskumar, Animal House Technician, for providing technical assistance in the execution of animal experiments. Dr. S. Seeni, Head, Dept. of Biotechnology, Mr. P. Padmesh, Scientist, and J.V. Reji, SRF, TBGRI, are acknowledged for their help in the DNA fragmentation analysis. Dr. (Mrs) Prabha Balaraman, Professor, Regional Cancer Research Centre, Trivandrum is gratefully acknowledged for providing photo-micrographic facilities.

\section{References}

1. Warrier PK, Nambiar VPD, Ramankutty C. Indian Medicinal Plants: A compendium of 500 species. Vol. 2. Chennai, India: Orient Longman Ltd.; 1995.

2. Autor Collective. A hand book of common medicine. Bejing: Peoples' Heals Press; 1969.

3. Srinivasan KK, Subramanian SS. Phytochemical screening of Emilia sonchifolia. Fitoterapia 1980;51:241-2.

4. Cheng D, Roder E. Pyrrolizidin alkaloids of Emilia sonchifolia. Planta Medica 1984;6:484-6.

5. Shylesh BS, Padikkala J. In vitro cytotoxic and antitumor property of Emilia sonchifolia (L) DC in mice. J Ethnopharmacol 2000;73:495-500.

6. Subramoniam A, Evans D A, Rajasekaran S, Pushpangadan P. Hepatoprotective activity of Trichopus zeylanicus extract against paracetamol induced hepatic damage in rats. Indian J Exp Biol 1998;36:385-9.

7. Mary KT, Kuttan G, Kuttan R. Partial purification of tumour reducing principles from Helianthes elastica. Cancer Lett 1994;81:53-6.

8. Babu BH, Jayaraman HN, Nair MG, Ajaikumar KB, Padikkala J. Free radical scavenging, anti-tumour and anti-carcinogenic activity of Gossypin. J Exp Clin Cancer Res 2003;22:581-9.

9. Eiji K, Okamoto A, Asada M, Nagamura S, Asai A, Saito H, Hirata T. Characteristic of anti-tumour activity of KW-2189, novel water soluble derivative of deucaromycine against murine and human tumours. Cancer Res1994;54:240410.

10. Giuliano M, Lauricella M, Calaruso G, Carabillo M, Emanuele S, Vento R, Tesoriere $\mathrm{G}$. The apoptotic effects and synergistic interaction of sodium butyrate and MG -132 in human retinoblastoma Y79 cells. Cancer Res 1999;59: 5586-95.

11. Subramoniam A, Rajasekaran S, Latha PG, Evans DA, Pushpangadan P. Immunomodulatory and anti-tumour activities of Janakia arayalpathra root. Fitoterapia 1996;57:140-4.

12. Wagner H, Bladt S, Zgainski EM. Plant drug analysis. Berlin, Heidelberg, New York, Tokyo; Springer- Verlag: 1984.

13. Jain NC. Schalms' veterinary haematology. $4^{\text {th }}$ ed. Philadelphia: Lea and Fabiger; 1986.

14. Reitman S, Frankel S. Colorimetric method for the determination of serum glutamic oxaloacetic and glutamic pyruvic transaminases. Amer J Clin Pathol 1957;28:56-63.

15. Kind PRN, King EJ. Estimation of plasma phosphatases by determination of hydrolysed phenol with antipyrine. J Clin Pathol 1954;7:322-30.

16. Wybenga DR, Pileggi VJ, Dirstine PH, Di Giorgio J. Direct manual determination of serum total cholesterol with a single stable reagent. Clinica Chemica 1970;16:980-4.

17. Jose TT, Panickkar B, Subramoniam A, Krishnan Nair M, Panicker KR. Antitumor property and toxicity of Barringtonia racemosa Roxb seed extract in mice. J Ethnopharmacol 2002;82:223-7.

18. Rebecca C, Daniel B, Yu S, Susan CK, Robert JC, Jasan DM. Anti-Oxidants reduce cyclooxygenase-2 expression, prostaglandin production and proliferation in colorectal cell. Cancer Res 1998;58:2323-7.

19. Steele VE, Boone CW, Lubert RA, Crowell JA, Holmes CA, Sigman CC, Kellof GJ. Preclinical drugs development paradigms for chemopreventives. Cancer Chemoprevention 1998;12:94-9.

20. Shylesh BS, Padikkala J. Antioxidant and anti-inflammatory activity of Emilia sonchifolia. Fitoterapia 1999;70:275-8. 